\title{
ANTI-GAMMA-GLOBULIN CONSUMPTION TEST IN HASHIMOTO'S DISEASE
}

\author{
BY \\ E. J. FIELD AND A. RIDLEY \\ From the Royal Victoria Infirmary, Newcastle upon Tyne
}

(RECEIVED FOR PUBLICATION APRIL 11, 1960)

A simple anti-gamma-globulin consumption test for use in suspected Hashimoto's disease is described. Results in cases with positive and negative tanned red-cell tests are described.

The anti-gamma-globulin consumption test was introduced by Steffen $(1954,1955)$ as a means of demonstrating either circulating or sessile antibody. Its application to the study of leucocyte and platelet antibodies and of auto-antibodies in rheumatic fever and arthritis has been reported, chiefly in the German literature ; recently, Steffen (1960) has summarized its uses in immunohaematology.

The present investigation was made with a closely similar method differing only in minor technical detail from that elaborated by Steffen and his colleagues. Hashimoto's disease has been used as a fairly well worked-out model of autoimmune disease, because an initial attempt to apply the method to the study of multiple sclerosis encountered certain difficulties.

In principle, the method is that of Coons' fluorescent microscopy (Coons, 1956) carried out in a test-tube. So far, we have applied it only to the demonstration of circulating antibody (indirect test of Steffen, 1960) since suitable biopsy specimens have not been available for the investigation of sessile antibodies (direct test).

To demonstrate circulating antibody capable of becoming fixed to thyroid tissue, the serum under test is brought into contact with a suitable finely dispersed thyroid preparation, so that any antibody present may have an opportunity for fixation. This substrate with its attached antibody is then thoroughly and repeatedly washed, so that adherent non-antibody globulins are removed. It is then exposed to a Coombs serum (anti-gammaglobulin) of known titre. Any antibody on the substrate will combine with some of the Coombs serum, reducing the titre found on re-estimation. If no antibody has become fixed upon the substrate then no such reduction should take place.

\section{Method}

A finely divided thyroid substrate was prepared by cutting up a block of fresh tissue, freed as far as possible from excess fat and connective tissue, at $30-40 \mu$ on a freezing microtome, sections being received into saline. Thorough disintegration was achieved in a blender, the suspension washed twice in saline at $5^{\circ} \mathrm{C}$., and then stored, until required, at $-20^{\circ} \mathrm{C}$.

Amounts of the wet substrate, each of $15.0 \pm$ $0.2 \mathrm{mg}$., were weighed out into each of a batch of six Wassermann tubes. To each tube 5 drops of serum (from a standard-sized pipette) were added. In earlier experiments two control sera were incorporated in each batch of six tubes. Recently, as confidence in the method has grown, only one has been used. Control sera were obtained from blood transfusion donors. Sera plus substrates were incubated for 30 minutes at $38^{\circ} \mathrm{C}$. in a water-bath and the substrate subsequently washed eight times with saline at room temperature. Coombs serum (Burroughs Wellcome) was diluted 1 in 64 and 10 drops (from a standard pipette) added to each of the substrates. These were now incubated for 20 to 30 minutes at $38^{\circ} \mathrm{C}$. and the Coombs serum then removed by centrifugation. From each sample of Coombs serum dilutions down to $1: 2,048$ were made, and these were plated out on a glass plate. To each drop, 1 drop of sensitized Group $\mathbf{O} \mathbf{R h}+$ erythrocytes (approximately in $10 \%$ suspension) was added and agglutination phenomena recorded at five and again at 10 minutes.

\section{Results}

The method was subjected to rigorous test by the assay of 100 "blind" sera kindly supplied by Professor G. A. Smart and Dr. S. G. Owen. The results showed very good correlation with the assessments previously made by Dr. Owen using the tanned red-cell method. Cases of Hashimoto's 
disease were diagnosed clinically (Professor Smart) ; some were confirmed histologically.

To the 54 " blind" controls in the series, 20 known blood-donor controls were added. Four gave misleading results and two of these turned out negative on repetition. Of the other two, one was weakly and the other strongly positive. The latter was from a case of disseminated lupus erythematosus.

Positive results were obtained in 16 of 18 cases of Hashimoto's disease in which the presence of circulating antibody had been demonstrated by a positive tanned red-cell test. The two negative sera were from histologically confirmed cases of Hashimoto's disease in which the tanned red-cell test yielded slight and moderate antibody concentrations respectively.

Positive results with an anti-gamma-globulin consumption test were also obtained in 10 of 15 cases of Hashimoto's disease in which the tanned red-cell test had been negative. In these 10 cases, the test was strongly positive in four, moderately strong in four, and weak in three.

The anti-gamma-globulin consumption test was also positive in all of seven cases of myxoedema with positive tanned red-cell tests.

\section{Discussion}

From these results it can be seen that the antigamma-globulin consumption test is a valuable adjunct to the serological diagnosis of Hashimoto's disease. Whilst it is positive in the great majority of cases which give a positive tanned red-cell test, it also picks out a considerable number of undoubted Hashimoto cases which yield negative results by this method.

This latter feature is of interest since Doniach, Hudson, and Roitt (1960) have recorded a case of classical Hashimoto's disease (Case 3) in which tanned red-cell, complement-fixation, and precipitin tests were all negative; the serum of this case, nevertheless, contained antibodies demonstrable by Coons' fluorescent antibody technique. In such cases the anti-gamma-globulin test might be informative.

The exact nature of the substrate in the test as described is not clear. Since it is washed so many times the greater part of its thyroglobulin may be presumed lost, and it appears to consist principally of the fibrous stroma of the gland, with a certain amount of parenchymatous debris. This raises the question as to whether yet another antigen may be present in the whole gland.

The authors would like to thank Professor G. A. Smart and Dr. S. G. Owen, who kindly provided all the "blind" sera and co-operated in checking the results against the "key" in their possession; Dr. S. M. C. Murray and Dr. T. Davies, of the Regional Blood Transfusion Centre, for provision of control blood specimens; Mr. R. A. Brack for technical advice ; Miss C. Smith for technical assistance : and the Medical Research Council for financial support.

\section{REFERENCES}

Coons, A. H. (1956). Int. Rev. Cytol., 5, 1

Doniach, D., Hudson, R. V., and Roitt, I. M. (1960). Brit. med. J.,

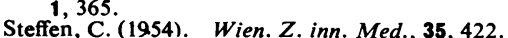

Steffen, C. (1954). Wien. Z. inn. Med.
(1955). Klin. Wschr., 33, 134.

(1960). J. Lab. clin. Med., 55, 9. 